\title{
Geotechnical Characterisation and Valorisation of Lateritic Soils in the Batchenga District of the Centre Region in Cameroon
}

\author{
Deodonne $\mathrm{K}^{*}$, Mbessa M and Gibering NT \\ Department of Civil Engineering, National Advanced School of Engineering Yaounde, University of Yaounde 1, Yaounde, Cameroon, France
}

Submission: January 20, 2021; Published: February 01, 2021

*Corresponding author: Deodonne K, Department of Civil Engineering, National Advanced School of Engineering Yaounde, University of Yaounde

1, Yaounde, Cameroon, France

\begin{abstract}
The main objective of this study is to contribute to the elaboration of a geotechnical map of the Central Cameroon region through, a geological characterisation of the basement first and, secondly the geo-technical and mechanical characterisation of the laterites of the induced zone with a view to their optimal use in the building and public works sector. For this purpose, a petrographic survey was carried out on a rocky sample and on four material samples identified as $\mathrm{OK} 1, \mathrm{OK} 2, \mathrm{BA} 1$ and BA2 from two profiles. Geotechnical identification and characterisation tests were done. In addition, mechanical tests were carried out on the Com-pressed Earth Blocks (CEB) and cylindrical specimens made from these materials. The results obtained show several conclusions; The laterites studied are all derived from the alteration of biotite and amphibole gneiss, which is made up of quartz, amphibole, feldspaths, plagioclase, biotite, zircon and opaque minerals; The samples studied have a high sand predominance and are rated as fair to poor pavement materials. The OK1 and BA1 samples belong to class $\mathrm{S} 4$ according to the recommendations of CEBTP [1] and therefore can be used as a form and base layer for traffic class T1. Samples OK2 and BA2 have the characteristics required for the manufacture of bricks.
\end{abstract}

\section{Introduction}

Foucault and Raoult [2] define laterites as ferruginous, hardened red tropical soils (especially ferralitic soils). there are residual of detrital soils resulting from the alteration of preexisting rocks and contain commonly a considerable quantity of iron and aluminum oxides, kaolinite and silica, but small quantities of titanium oxides, manganese, magnesium, etc [3]. The soil type has the characteristics of a hard, impenetrable, and very difficult to change if dry conditions [4]. In tropical areas in general, and in Cameroon in particular, laterites are of great interest because of their abundance, availability and easy workability (Figure 1) [3-7]. These laterites are the most commonly used soils in civil engineering works, particularly in road construction in most countries of intertropical region and in construction buildings, which are the basis of the socio-economic development of most communities. Prior knowledge of the geological, geotechnical and mechanical characteristics of this type of mate-rial throughout the Cameroonian territory for subsequent optimal exploitation in the construction and public works sector (the bearer of development) is ideal and remains a very worrying activity for Cameroonian researchers [8-13].
The District of Batchenga is all the more attractive for researchers as it is not only a climatic transition zone between forest and savanna but also and above all, it has been chosen as an investment zone within the framework of the emergence of Cameroon in the year 2035. Laterite being a heterogeneous material, it has a complex behaviour. This is why the material must be well identified before any decision is taken with a view to its possible valorisation. The present study proposes to carry out, first, a geological char-acterisation of a rock sample taken from the Nkolmekok quarry and, secondly, a geotechnical and me-chanical characterisation of the surface formations of the Okongolo and Balong localities, all in the Batchenga district, Lékié division in the Central Region of Cameroon, with a view to optimise their use in the civil engineering sector.

\section{Materials and Methods}

Several field works were realised and devoted to lo-calise monitoring sites and sampling. Laboratory tests included identification (Atterberg limits, parti-cle size analysis and methylene blue test) and char-acterisation tests (California Bearing Ratio, Proctor test and mechanical test). 


\section{Materials}

The two sampling points for laterites are located in Okongolo and Balong respectively, the rock quarry is in Nkolmekock. These three points have the respective coordinates N04 17' 36" E11 39' 12"; N04 16' 17" E11 39' 23"; N04 13' 13" E11 35' 39". The observation of the profiles was done vertically from bottom to top and consisted in the visual identification of all the levels at different weathering profiles. The characterisation criteria used were texture, thickness and mineralogy. Soil samples were taken using a shovel and pickaxe. The samples were placed in bags previously labelled with the initials of the name of the study area (BA) or (OK) followed by the numbers 1 and 2 indicating the level of sampling.

Table 1: Classification of soil through preliminary tests.

\section{Laboratory work}

\section{Geological work}

The petrography of the rock was carried out in two stages including the realisation of the thin slide at the Institute of Geological and Mining Research of Cameroon (IRGM) and the description of this thin slide using a polarizing optical microscope of Leitz Wetzlar type.

\section{Identification tests and classification}

\section{Preliminary tests}

Preliminary tests involve defining the nature of soils using basis human senses. They are indicated in Table 1.

\begin{tabular}{|c|c|c|c|}
\hline \multirow{2}{*}{ Trials } & Sandy & Silty & Clayey \\
\cline { 2 - 4 } & & Fine Fraction & \\
\hline Sight & Snpleasant sensation within the teeth & No unpleasant sensation & Sticky in contact with the tongue \\
\hline \multirow{2}{*}{ Taste } & Rough & Averagely plastic & Plastic and sticky \\
\hline Touch & Rough & Averagely plastic & Plastic and sticky \\
\hline Radiance & &
\end{tabular}

Atterberg limits, grains size analysis and methylene bleu tests

The Atterberg limits and the particle size analysis are carried out respectively according to NF P 94-051 [14], NF EN 933-1 [15] and NF P 94-057 [16].

\section{Characterisation tests}

\section{California Bearing Ratio and Proctor tests}

The California Bearing Ratio (CBR) and proctor tests are realized following respectively NF P 94-078 [17] and NF P 94-093 [18].

\section{Mechanical tests}

The samples taken were subjected to mechanical tests, including simple compression according to NF EN 12390-2 [19], traction by splitting according to NF EN 12390-6 [20] and traction by bending on cylindrical specimens and compressed earth blocks made up. Cylindrical specimens for compressive and tensile tests by splitting are obtained by compaction in a CBR mould (Figure 1). While the Compressed Earth Blocks (CEB) for compression and bending tensile tests are obtained by compacting using a GEO 50 type mould (Figure 2).

Results

\section{Presentation of the materials studied}

The rocky material studied comes from the Nkolmekok quarry located on the Obala-Batchenga road. This quarry covers an area of 17.25 ha. The bedrock has a dark grey to light grey overall appearance and has more or less distinct bedding in some areas. There are also some elements of biotite and feld-spaths in sizes ranging from a few $\mathrm{mm}$ to $\mathrm{cm}$. The four laterite samples that were subjected to the study were taken from two distinct profiles respectively. OK1 and OK2 came respectively from the soft clay and nodular clay levels of the Okongolo soil profile (Figure 3), while BA1 and BA2 came respectively from the same levels of the Balong soil profile (Figure 4).

\section{Identification and classification of studied materials}

\section{Rock materials: Petrography}

In thin layers, the rock has a heteroganular grano-blastic texture composed of $25 \%$ quartz, 20\% pla-gioclase, 20\% amphibole, $19 \%$ biotite and $15 \%$ potassium feldspaths (Figure 5). The accessory phase represents $1 \%$ and consists of zircon and opaque minerals. The rock studied is a gneiss with biotite and amphibole (Figure 5).

\section{Lateritic materials: Plasticity}

The consistency of the materials is shown in Table 2 and Figure 6. It shows that the $0 \mathrm{~K} 2$ and BA2 materials are not very plastic and can be used for brick making according to the plasticity diagram of Bain and Highley (Figure 6) [21-23]. However, the plasticity of a material can be im-proved (Tejiopgap et al., 2003); Ok1 is moderately plastic while BA1 is very plastic. The projection of all the samples studied in the Casagrande diagram (Figure 7) shows that it is a very plastic stringer (Lt) for BA1 and strings (Lp) and organic soils with little plasticity (Op) for the samples OK1, OK2 and BA2. The samples studied have a swelling potential of less than 1.5 and are therefore classified as low-swelling soils as shown in Table 2. 


\section{Civil Engineering Research Journal}

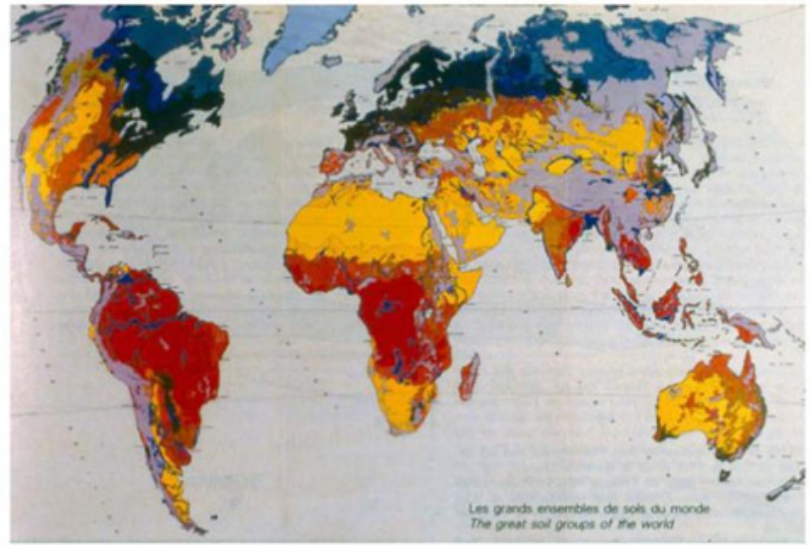

Figure 1: Soil distribution in the world: source AFES, world congress 1998. Lateritics in red.
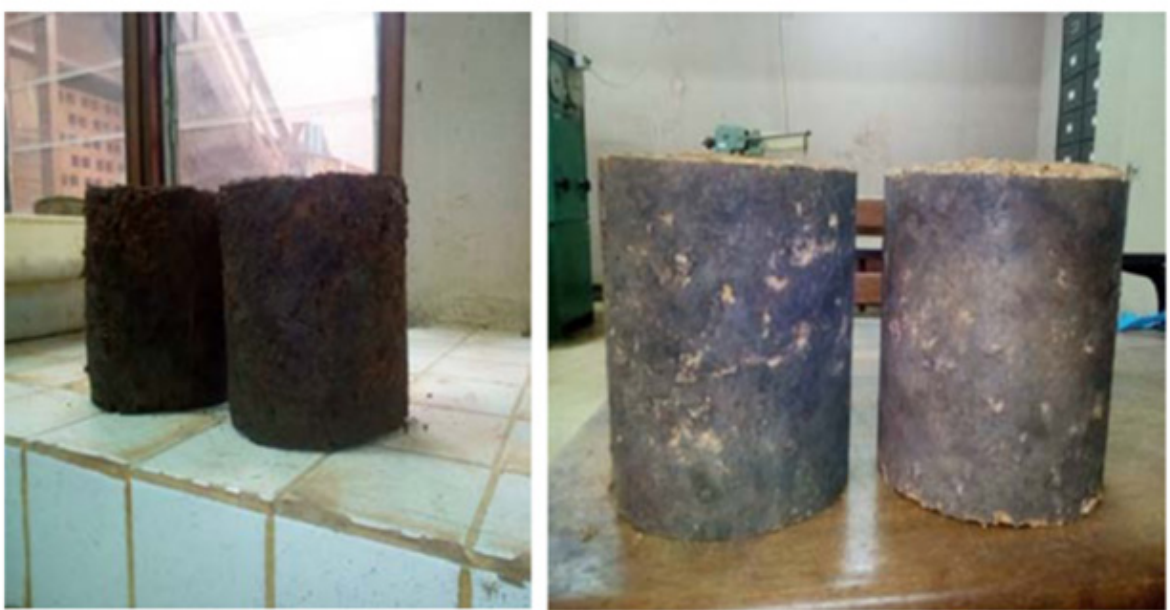

(a) specimens made from BA1 material (b) specimens made from OK1 material

Figure 2: Cylindrical specimens of $15 \times 12 \mathrm{~cm}$ of lateritic gravel from the Batchenga area before single compression and tensile test.

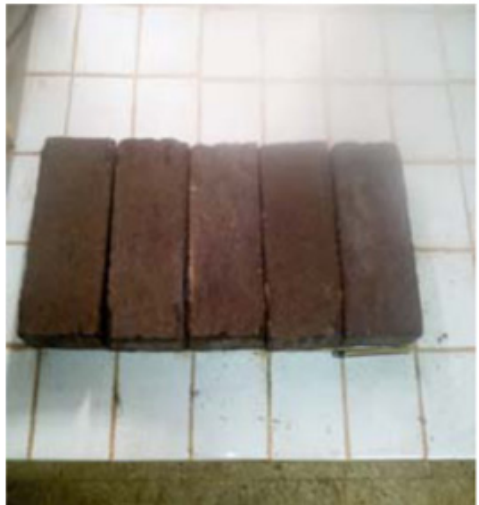

(a) specimens made from $\mathrm{OK}_{2}$

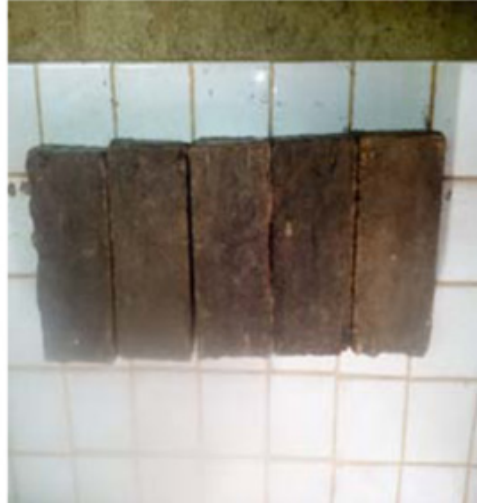

(b) specimens made from $\mathrm{BA}_{2}$

Figure 3: Compressed earth blocks of dimensions $5 \times 11 \times 21 \mathrm{~cm}$ made from Batchenga clay materials before simple compression and tensile tests. 


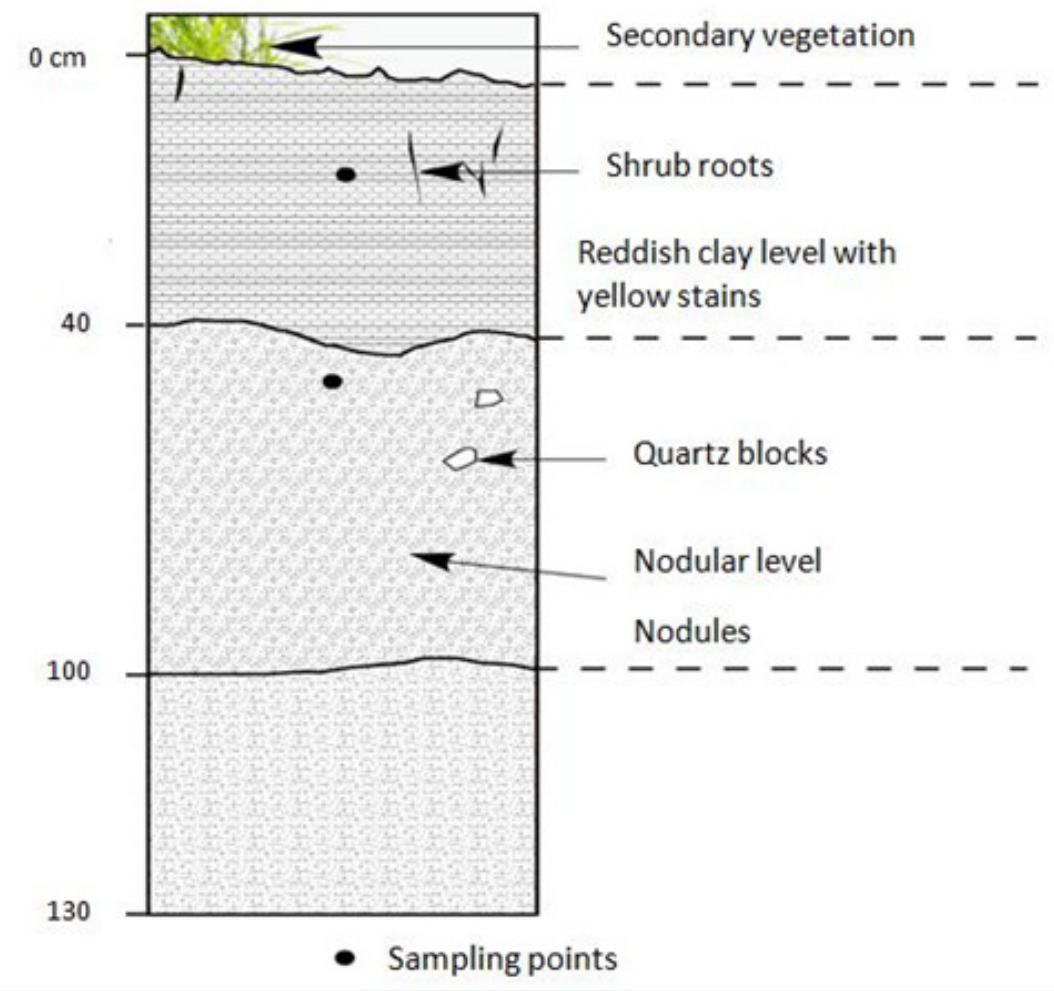

Figure 4: Pedological section of gravel and clay materials from the Okongolo sampling site.

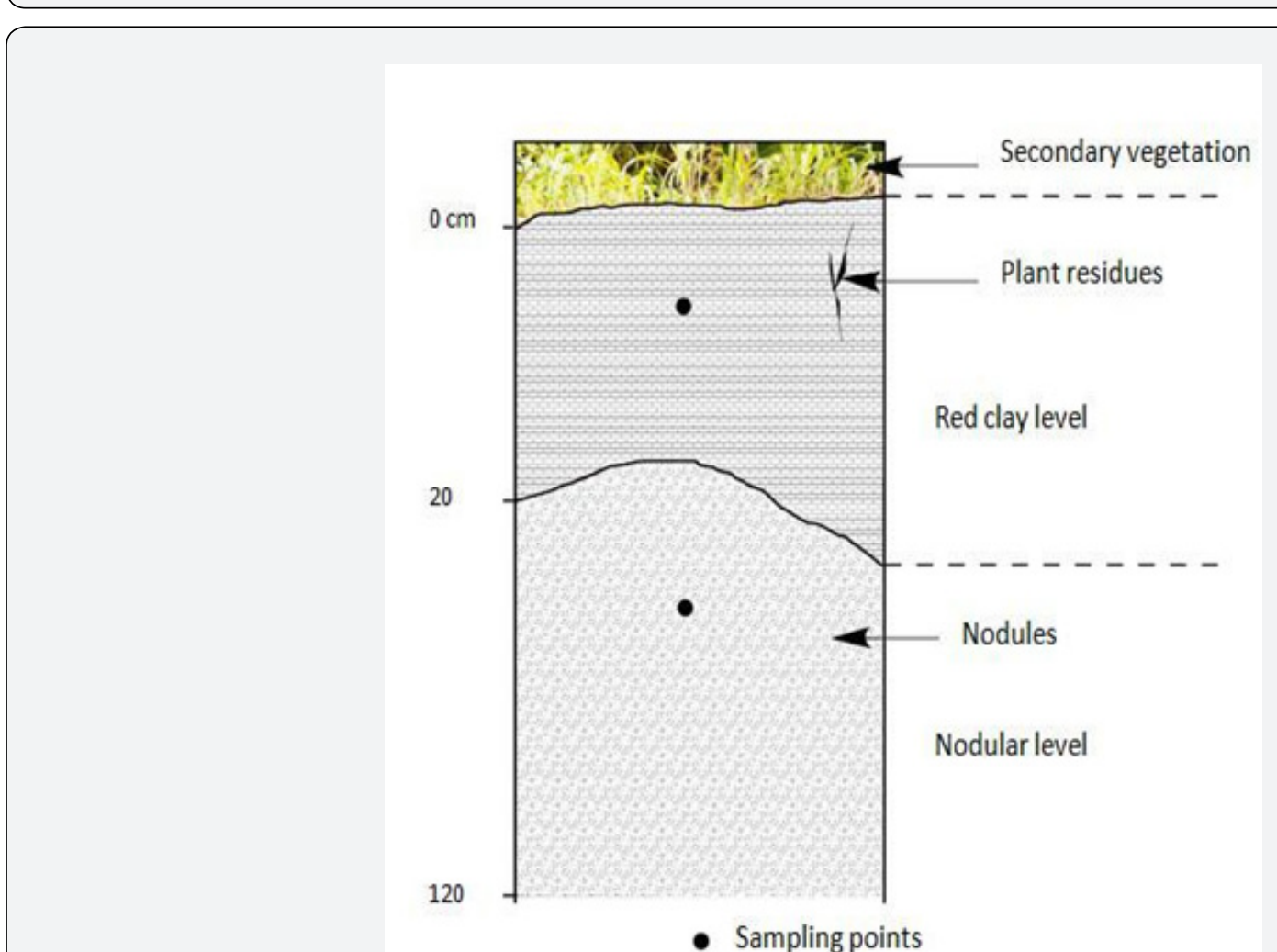

Figure 5: Pedological section of gravel and clay materials from the Balong sampling site. 


\section{Civil Engineering Research Journal}

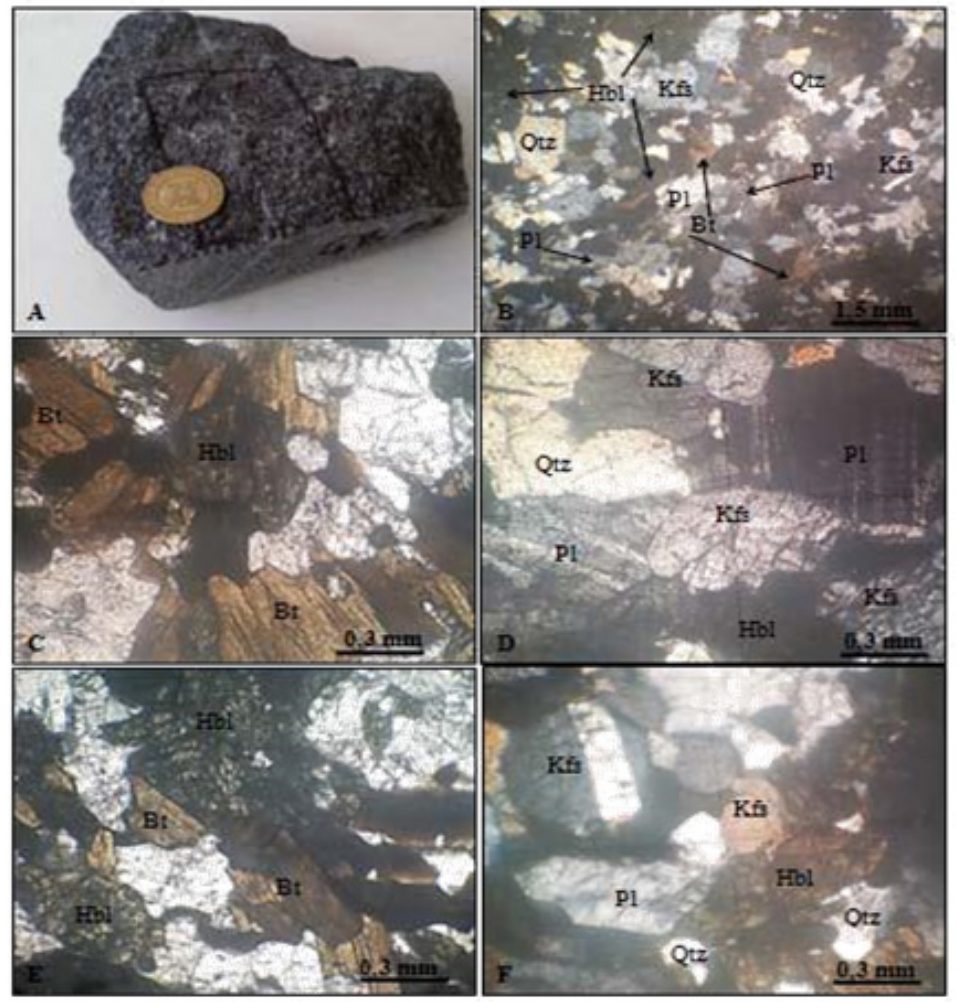

Figure 6: Macroscopic and micro-photographic aspects of biotite and amphibole gneiss.

A: Macroscopic aspect of the rock sample studied

B, D, F are microphotographs observed in Analysed Polarised Light (APL).

C, E are microphotographs observed in Non-Analyzed Po-larized Light (NAPL).

Pl.: Plagioclase; Qtz : Quartz; Bt. : Biotite; Hbl.: Hornblende; Kfs. : Potassium feldspaths Opq : Opaque minerals.

Table 2: Swelling potential of soils according to their plasticity index [23].

\begin{tabular}{|c|c|c|}
\hline Swelling potential & Epsilon $\mathbf{c}$ & Plasticity Index (Ip) \\
\hline Low & $0-1.5$ & $0-10$ \\
\hline Medium & $1.5-5$ & $10-20$ \\
\hline High & $5-25$ & $20-35$ \\
\hline
\end{tabular}

\section{Grain size distribution}

Table 3 shows the values of the different grain size distribution. Examination of the results in Table 3 shows that the OK2 and BA2 samples have spread curves and are classified as "clay sands" with traces of silt and gravel for $0 \mathrm{~K} 2$ and with some silt and gravel for BA2. The fine fraction is $46 \%$ and $47 \%$ respectively for OK2 and BA2. The sieve size curves for the BA2 and OK2 samples incorporate the specification spindles for CEB (NC 102-114, 20022006) as shown in Figure 8. These samples can be used for the production of perforated bricks according to Table 4 because their grain size fraction below 2 microns is $30 \%$ and $25 \%$ respectively. According to Winkler's diagram (Figure 9), OK2 and BA2 can be used for the production of dense bricks. The OK1 and BA1 samples have spread curves and are classified as "gravelly sand" with some clay and silt for OK1 and sandy gravel with some clay and traces of silt for BA1. The OK1 and BA1 samples show $44 \%$ and $22 \%$ fines respectively. BA1 can be used as a base course and foundation course since its grading curve fits in part into the specification ranges for base and foundation courses as shown in Figures 10 and 11. 


\section{Civil Engineering Research Journal}

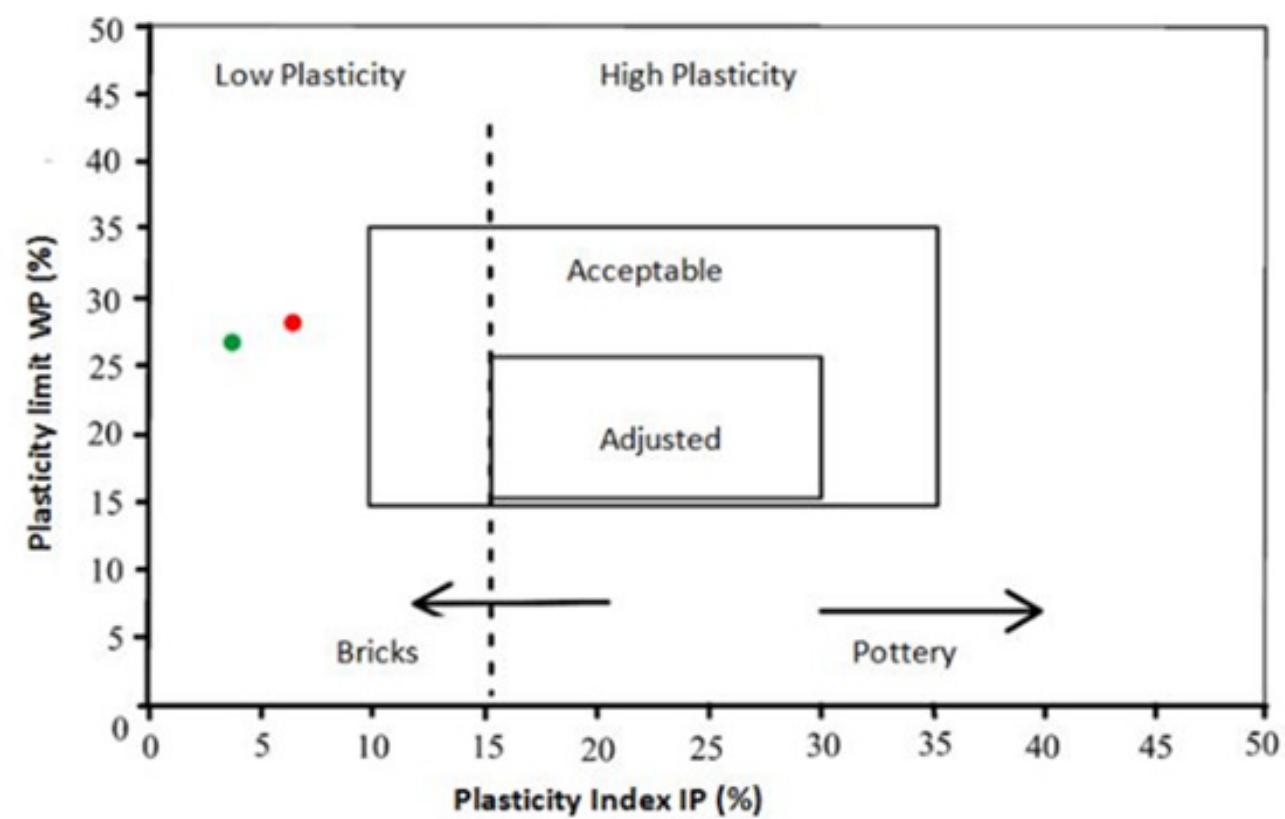

Figure 7: Position of materials in the plasticity diagram Bain and Highley [21].

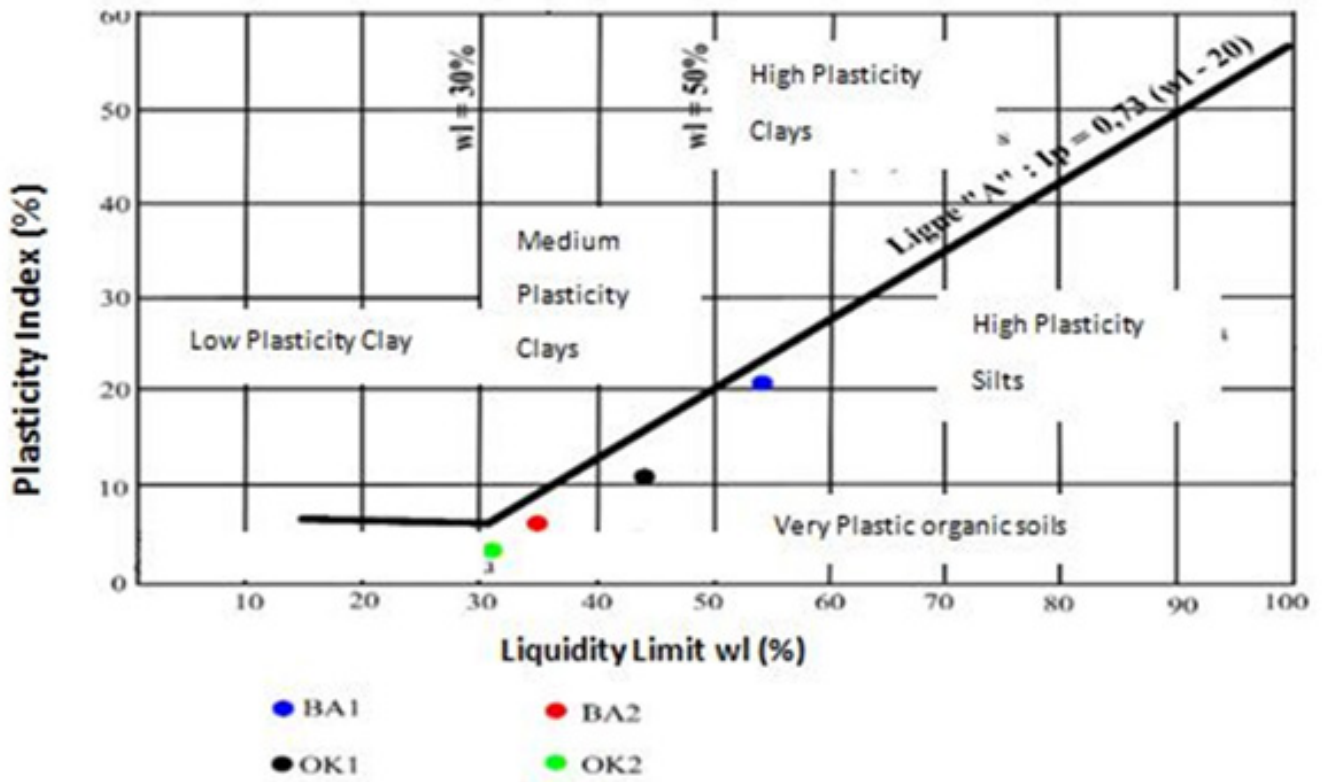

Figure 8: Position of weathering materials in the Casagrande plasticity chart [22].

Results obtained from the particle size analysis and Atterberg limits classifies according to the LPC classification OK1 and OK2 as silty sand, BA1 is a Silty gravel meanwhile BA2 is Clayey sand. According to the HRB classification; OK1 belongs to class A-7-5 as clayey soil; OK2 to class A-4 as loamy soil; BA1 to class A-2-7 as silty or clayey gravel and sand and BA2 to class A-7-6 as clayey soil. All these materials are classified as fair to poor for road construction.

\section{Value of Methylene blue}

The value of methylene blue found is $11 \mathrm{~g} / 110 \mathrm{~g}$ soil, which qualifies the materials as at the threshold separating clay soils 


\section{Civil Engineering Research Journal}

from very clay soils, with moderate swelling potential. In addition, the activity of clay fraction is estimated at 0.61 . This value is less than 0.5 obtained by Ekodeck [10]. According to the norm NF P
94-068 sand belongs to the group of inactive soils, this is due to the quartz nature of sands [24]

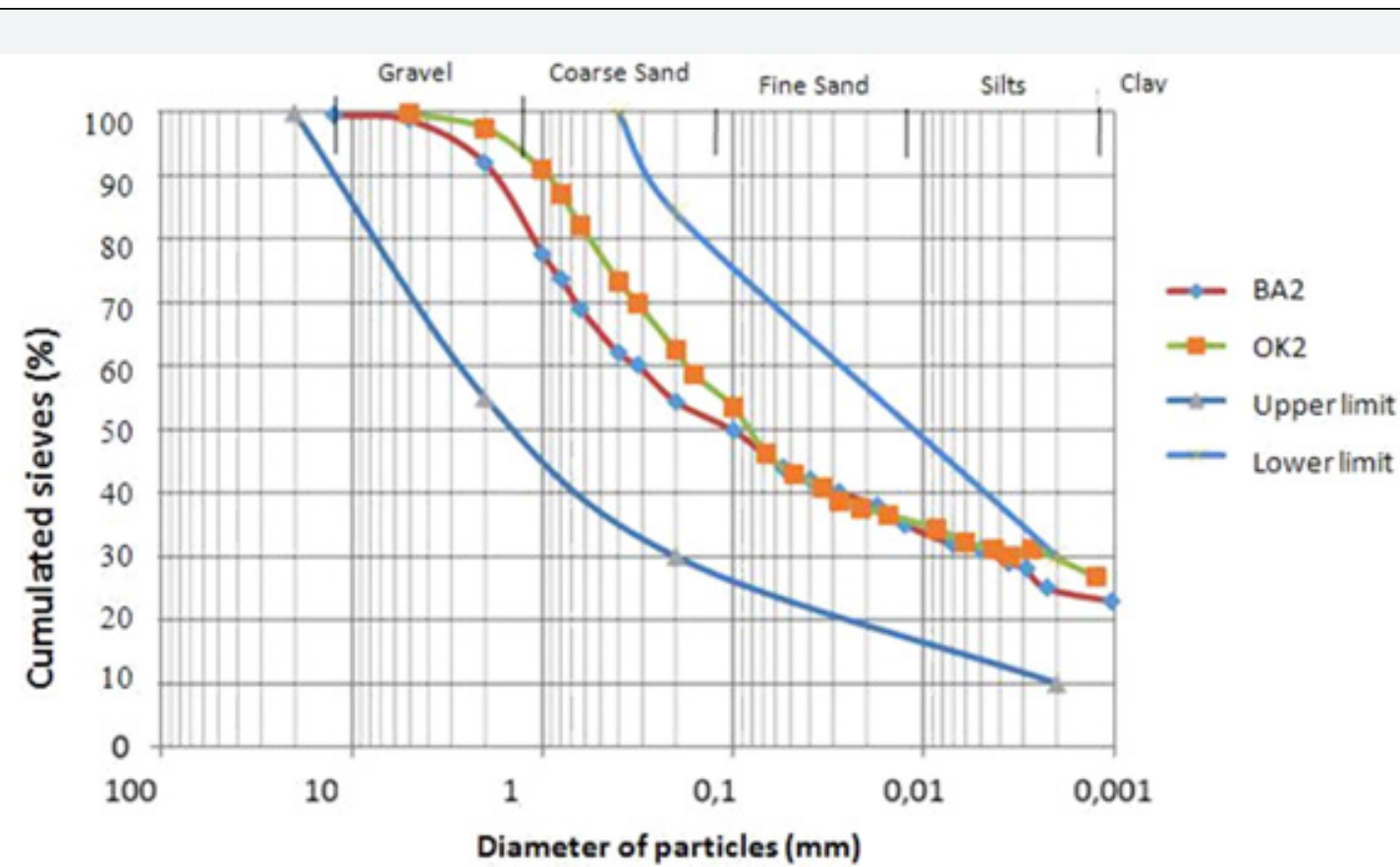

Figure 9: Particle size curve of BA2 and OK2 materials in the specification ranges for CEB (NC 102-114, 2002-2006).

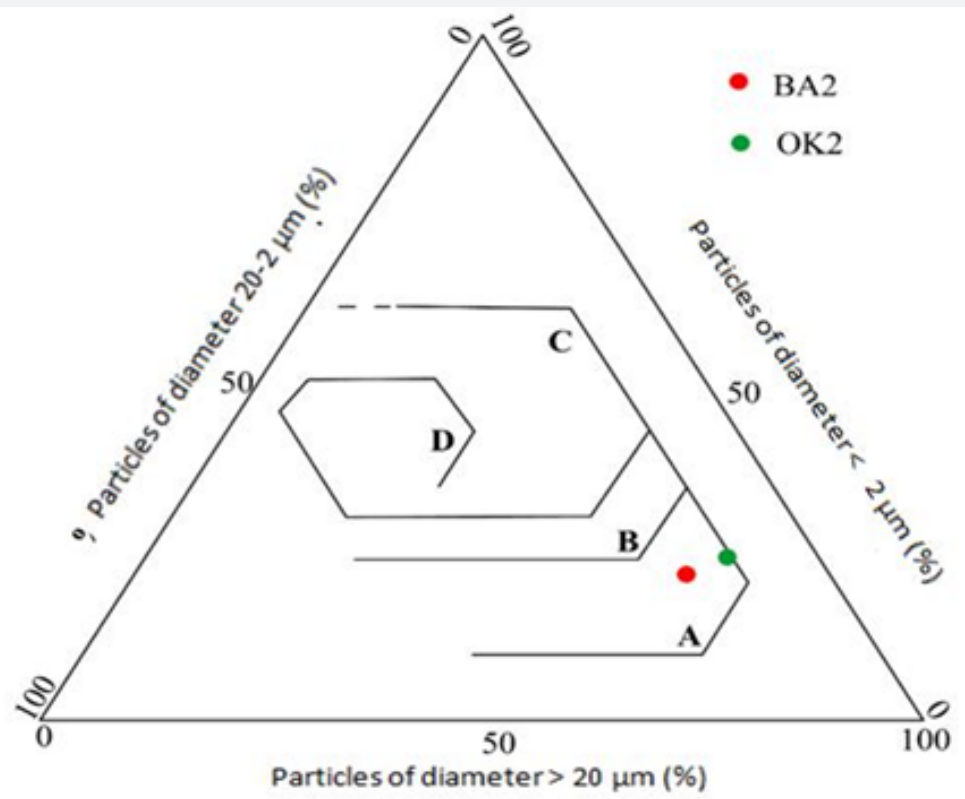
A: Solid bricks
B:
Perforated vertical blocks
C: Tiles and Masonry blocks
D Hollow products

Figure 10: Position of materials in Winkler's (1954) diagram in [29]. 


\section{Civil Engineering Research Journal}

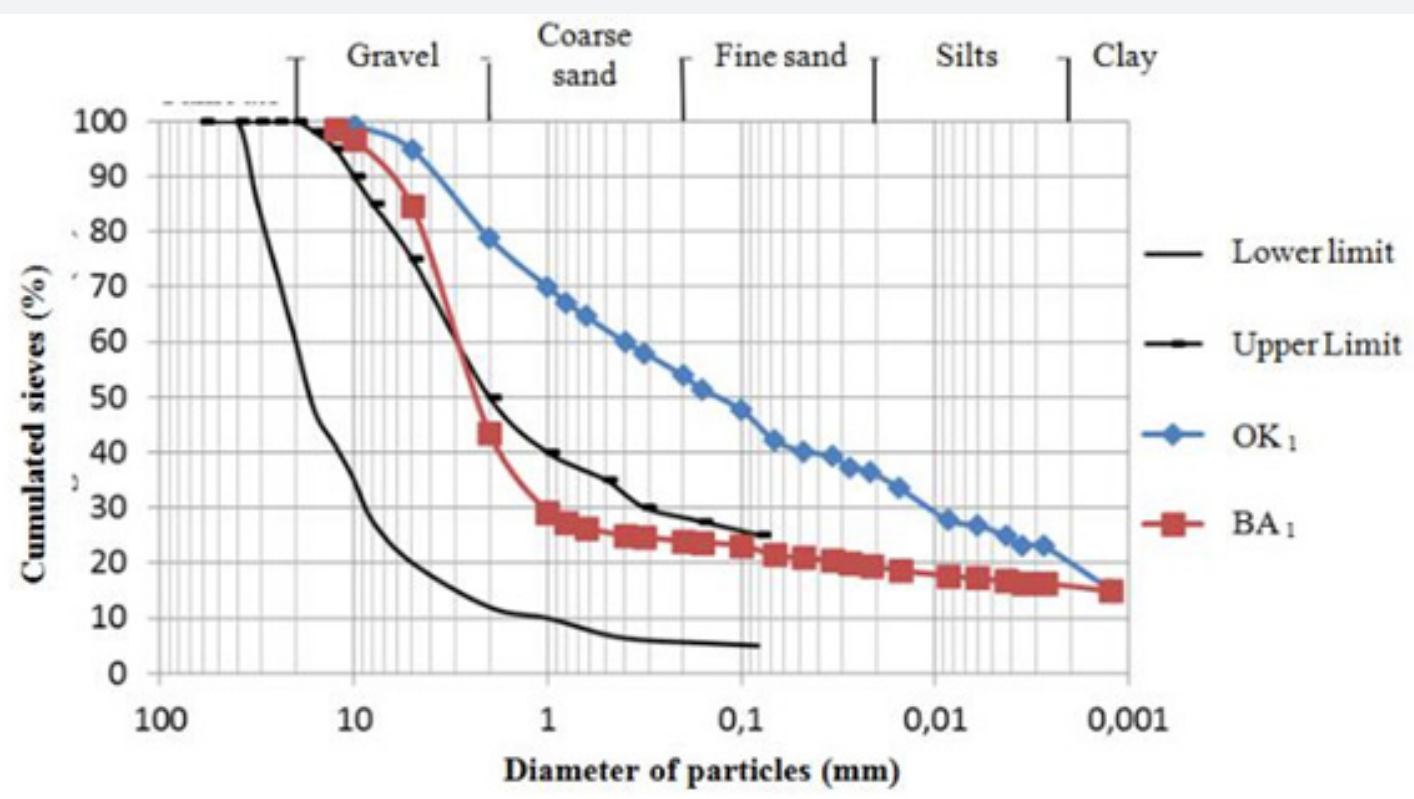

Figure 11: Position of OK1 and BA1 materials in base layer specification zones [1]

Table 3: Percentage of the different grain size classes of the materials studied.

\begin{tabular}{|c|c|c|c|c|c|}
\hline \multicolumn{6}{|c|}{ Diameter of particles $(\mu \mathrm{m})$ and their percentage } \\
\hline \multirow{3}{*}{ Particles Samples } & Gravel & Coarse Sand & Fine sand & Silt & Clay \\
\hline & $2000<\Phi$ & $200<\Phi$ & $20<\Phi$ & $2<\Phi$ & \multirow{2}{*}{$\Phi \leq 2$} \\
\hline & $\leq 20000$ & $\leq \mathbf{2 0 0 0}$ & $\leq 200$ & $\leq \mathbf{2 0}$ & \\
\hline OK1 & 22 & 24 & 18 & 16 & 20 \\
\hline OK2 & 3 & 36 & 23 & 8 & 30 \\
\hline BA1 & 57 & 18 & 5 & 5 & 15 \\
\hline BA2 & 8 & 37.4 & 16.49 & 13.02 & 24.91 \\
\hline
\end{tabular}

\section{Characterisation of the materials studied}

\section{Proctor Data}

The curves of dry density versus moisture content are shown in Figures 12 and 13. From these curves, the value of the optimal moisture content and the optimal dry density of $18.82 \%$ and 2.19 for gravelly sand (OK1) and $18.6 \%$ and 2.45 for sandy gravel (BA1) are deducted respectively. These values are different from $10 \%$ and 2.03 obtained by Ndzié [25] on the lateritic gravels of Batchenga. This difference can be explained by the percentage and nature of the fine particles. OK2 and BA2 have the same maximum dry density of 1.28 close to the range 1.30 to 1.70 proposed by Mamba Mpele [26] for the manufacture of CEB. The optimum water content of these same materials is of the order of $18.9 \%$. Figure 14 show the CBR index curves as a function of the dry density of each material. The figures for OK1 and BA1 show $18 \%$ and $18.5 \%$ respectively. The CBR index values are lower than the $46 \%$ value obtained by Ndzié in 2014 in Batchenga and are higher than the $6.90 \%$ value obtained by Guetcho [27] in Tiébélé, Burkina Faso. The difference ob served in the CBR values of the different samples studied can be explained by the percentage and nature of the fine particles. According to the CEBTP specifications and following the table of bearing capacity class, BA1 and OK1 belong to class S4 to the recommendations of CEBTP [1] $(15<\mathrm{CBR}<30)$ and can therefore be used as a base and subbase layer for traffic class T1 Figures 15 and 16. There is a correlation be-tween CBR value and dry density according to Nkoumou. The same authors estimate that the CBR of a material increases with its dry density. The mechanical behaviour of the samples studied shows that the values for tensile strength by splitting have a similar evolution to that of compression for OK1 and BA1 (Table 5). They decrease as the number of curing days increases. The compressive strengths 5 and 5.9 MPa respectively for $\mathrm{OK} 2$ and BA2 meet the Cameroonian standard, which requires that the strength of CEB be greater than or equal to $4 \mathrm{MPa}$. 


\section{Civil Engineering Research Journal}

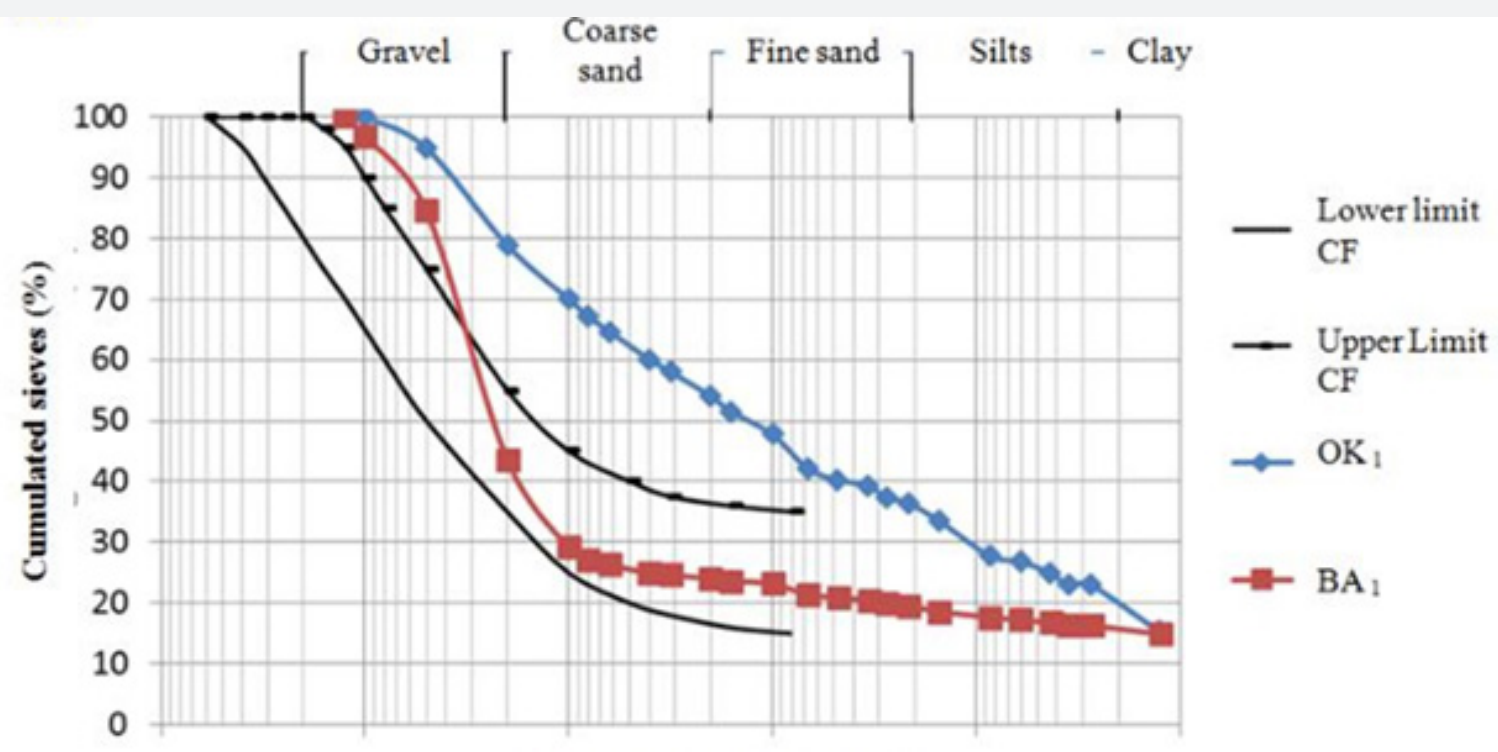

Diameter of particles ( $\mathbf{m m})$

Figure 12: Position of OK1 and BA1 materials in the specification zones in the foundation layer [1]
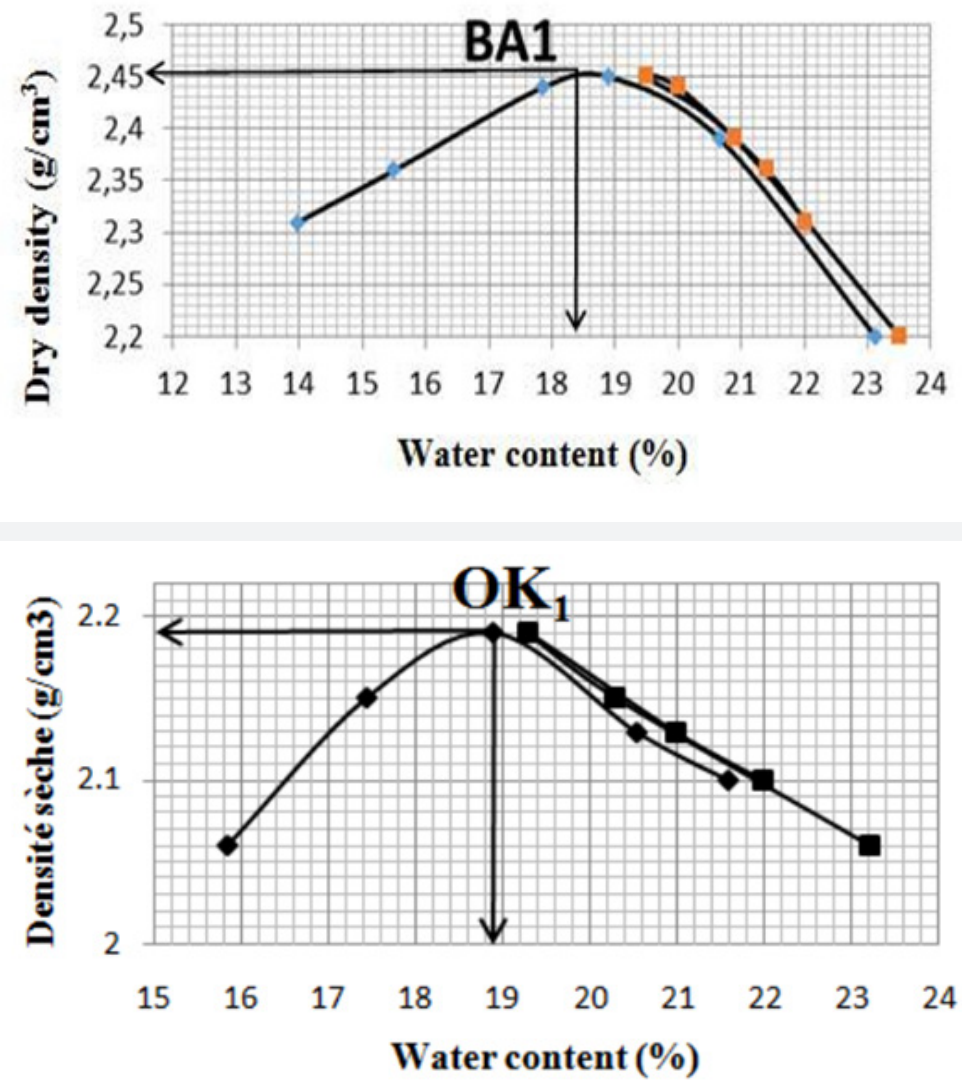

Figure 13: Proctor curves of BA1 and OK1. 


\section{Civil Engineering Research Journal}

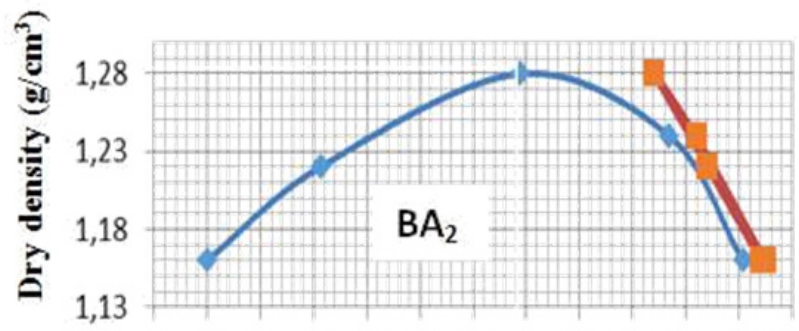

Water content $(\%)$

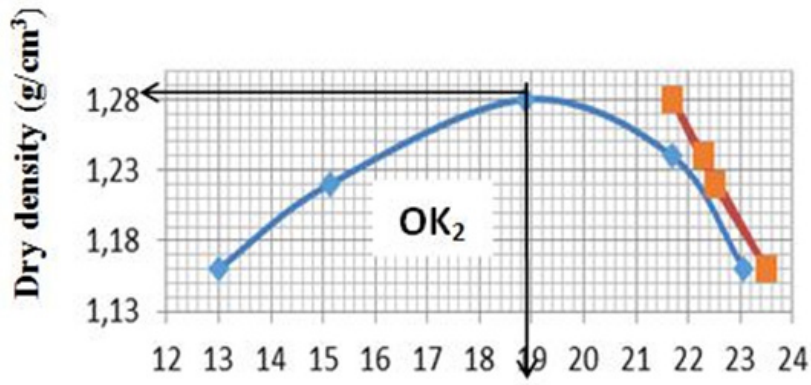

Water content (\%)

Figure 14: Proctor curves of BA2 and OK2.

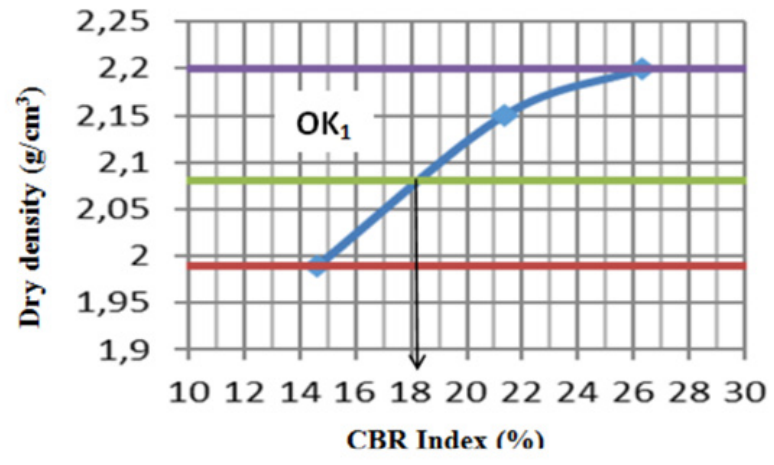

Figures 15: show the CBR index OK1.

Table 4: Relationship between grain size composition and type of ceramic products [24].

\begin{tabular}{|c|c|}
\hline Grain fraction $<2 \boldsymbol{\mu m}(\mathbf{\%})$ & Achievable ceramic products \\
\hline $15-25$ & Solid bricks \\
\hline $25-35$ & Perforated bricks \\
\hline $35-45$ & Hollow bricks, drains \\
\hline $45-50$ & Cinder blocks, tiles \\
\hline
\end{tabular}




\section{Civil Engineering Research Journal}

Table 5: Values of simple compressive and tensile strength by splitting of OK1 and BA1 lateritic gravel pits.

\begin{tabular}{|c|c|c|c|c|}
\hline \multirow{2}{*}{ Sample } & Curing age (age) & Compressive strength (bars) & Flexural tensile strength (Mpa) & Tensile strength (bars) \\
\hline \multirow{2}{*}{ OK1 } & 4 & 3 & $/$ & 1 \\
\cline { 2 - 5 } & 7 & 2,6 & $/$ & 0,7 \\
\hline \multirow{2}{*}{ BA1 } & 4 & 1 & $/$ & 0,6 \\
\cline { 2 - 5 } & 7 & 0,8 & 0,27 & 0,2 \\
\hline BA2 & 14 & 5 & 0,3 & $/$ \\
\hline
\end{tabular}

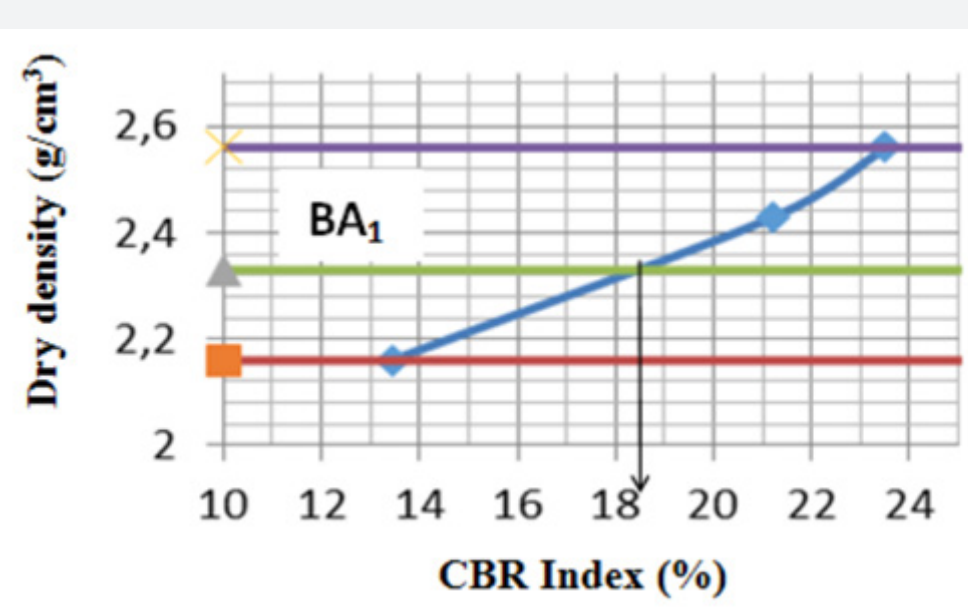

Figure 16: CBR curves of the BA1 sample.

\section{Conclusion}

The main objective was to contribute to the elaboration of a geotechnical map of the region of Central Cameroon through, a geological characterisation of the basement and, the geotechnical and mechanical characterisation of laterites of the area raised with a view to their optimal use in the building and public works sector. A petrographic study was carried out on a rock sample and four material samples (OK1, OK2, BA1, BA2) from two profiles from the geo-technical identification and characterisation tests were taken. In addition, mechanical tests were carried out on the BTCs and cylindrical specimens made from these materials. The results obtained suggest that (l) the OK1 sample is a Limestone sand belonging to class A-7-5 according to the HRB classification, its plasticity is $11 \%$, its optimum water content is $18.82 \%$ for a maximum dry density of 2.19 and its CBR is $18 \%$-the compressive strengths at 4 and 7 days are respectively 3 and 2.6 Bars while the tensile strengths for the same ages are respectively 1 and 0.7 Bars; (2) the OK2 sample is a silty sand belonging to class A-4 according to the HRB classification, its plasticity is $4 \%$, its optimum water content is $18.9 \%$ for a maximum dry density of 1.28 the compressive and flexural strengths at 14 days are 5 and $0.27 \mathrm{MPa}$ respectively; (3) the BA1 sample is a silty gravel, belonging to class
A-2-7 according to the HRB classification, its plasticity is $21 \%$, its optimum water content is $18.6 \%$ for a maximum dry density of 2.45 and a CBR of $18.5 \%$-the compressive strength at 4 and 7 days is 0.6 and 0.2 Bars respectively, while the tensile strength for the same ages is 1 and 0.7 Bars respectively; (4) sample BA2 is a clayey sand belonging to class A-7-6 according to the HRB classification, its plasticity is $7 \%$ and its optimum moisture content is $18.95 \%$ for a maximum dry density of 1.28 - the compressive and flexural strengths at 14 days are 5.9 and $0.3 \mathrm{MPa}$ respectively; (5) The samples studied have a high sand predominance and are qualified as fair to poor pavement material. The OK1 and BA1 specimens be-long to class S4 to the recommendations of CEBTP (1984) and can therefore be used as a subgrade and sub-base layer for traffic class T1. Samples OK2 and BA2 have the characteristics required for the manufacture of bricks.

\section{References}

1. (1984) CEBTP A practical guide to road design for tropical countries. Secretariat of State for Foreign Affairs in charge of Cooperation, Paris p: 157.

2. Foucault A, Raoult JF (2001) Dictionary of geology. Du-nod, $5^{\text {th }}$ ed.

3. Issiakou MS (2016) Characterization and valuation of lateritic materials used in road construction in Niger. Other. University of Bordeaux, French. 


\section{Civil Engineering Research Journal}

4. Saing Z, Samang L, Harianto T, Patanduk J (2017) Mechanical characteristic of ferro laterite soil with cement stabilization as subgrade material. International Journal of Civil Engineering and Technology (IJCIET) 8 (3): 609-616.

5. Autret P (1983) Laterites and gravelly laterites. Document of the Institute of Science and Technology Equipment and Environment for Development France p: 38

6. Sikali F, Djalal ME (1987) Use of laterites in road engineering in Cameroon P: 11.

7. Legros JP (2013) Laterites and other soils of intertropical zones. Acad. Sci. and Letters from Montpellier, Conf. ${ }^{\circ}{ }^{\circ} 4252$, Screening of 12/09/2013. Bull. de l'Acad 44: 369-382

8. Mbessa M, Deodonne K, Wansi LMW (2019) Lithostabilisation of Karal: Case of Maroua at the Far North Region of Cameroon.

9. Mamba M, Nzengwa R, Tsomgné I (2001) Formulation of an earth cement mortar for walls implemented using the pies technique. Africa science $07(2): 1-15$

10. Ekodeck GE (1976) Contribution to the study of the nature and geotechnical behavior of superficial swelling deposits of North Cameroon. $3^{\text {rd }}$ cycle PhD thesis, University of Grenoble I p: 181.

11. Lambiv Dzemua, G, Gleeson SA, Schofield PF (2013) Mineralogical characterization of the Nkamouna Co-Mn laterite ore, southeast Cameroon. Miner Deposita 48: 155-171.

12. Baana AM, Mamba M, Danwé R, Elime BA (2016) Effects on sand on densities of swelling clay from the far north region of Cameroon, International Journal of Information Research and review 08: 27192724.

13. Honore Takala B, Michel M (2019) Geotechnical Characterization of the Batoufam Lateritic Gravels (West Cameroon) for Road Construction Purpose. In: Kallel A. et al. (eds) Recent Advances in Geo-Environmenta Engineering, Geomechanics and Geotechnics, and Geohazards. CAJG 2018. Advances in Science, Technology \& Innovation (IEREK Interdisciplinary Series for Sustainable Development). Springer, Cham.

14. NF P 94-051. (1993) Soils, reconnaissance and testing. Determination of the Atterberg Limits. Limit of liquidity with the shovel-Limit of plasticity with the roller. AFNOR p: 16

15. (2012) NF EN 933-1 Soils: reconnaissance and testing. Particle size analysis. Method by sieving under water. AF-NOR p: 16.

16. (1996) NF P 94-057 Soils: reconnaissance and testing. Particle size analysis. Sedimentation method. AFNOR p: 20
17. (1997) NF P 94-078. Soils: reconnaissance and tests-CBR index after immersion. immediate CBR index. Por-tant Immediate-Measurement index on sample compacted in the CBR mold. AFNOR p: 11.

18. (2014) NF P 94-093 Proctor Normal Test - Modified Proctor Test. AFNOR p: 17

19. (2019) NF EN 12390-2 Tests for hardened concrete - Part 2: confection and conservation of test specimens for resistance tests. AFNOR p: 18.

20.(2012) NF EN 12390-2 Tests for hardened concrete - Part 6: determination of the tensile strength by splitting test specimens. AFNOR p: 18

21. Bain JA, Highley DE (1970) Regional appraisal of clay resources. A challenge to the clay mineralogist. In: (M.M. Mortland\& V.C. Farmer, editors). Proceeding of the IV International Clay Conference, AIPEA p: 437.

22. Casagrande A (1948) Classification and identification of soils. ASCE Transactions 113: 901-930.

23. Millogo Y, Traore K, Ouedraogo R, Kabore K, Blanchart P, et al. (2008) Geotechnical, mechanical, chemical and mineralogical characterization of a lateritic gravels of Sapouy (Burkina Faso) used in road construction. Const Build Mat 22(2): 70-76.

24. Manjia, M (2012) Cours de construction enterre, Ecole Nationale Supérieure Polytechnique de Yaoundé-Cameroun p: 23.

25. Ndzié Mvindi (2011) Petrological and geotechnical characterisation of lateritic rocks and gravels in the Batchenga region (Central Cameroon) for use in road construction. Mem. Fac Sci. Univ. Yaoundé I p: 71.

26. Mamba MPELE (1997) Some properties of laterites from Cameroon and criteria to be applied to raw materials for the manufacture of earth blocks. Journal of Cameroon on Building Materials 2(2): 19-23.

27. Guetcho T (2010) Stabilisation study of road pavements based on laterites with parkiabiblobosa extracts. Mem. Master's Degree, Inter. Institute of Water and Environment Engineering p: 80

28. Cere L, Mazel F (1994) Clay characterisation. ENSCI Limoges, France p: 71.

29. Reeves GM, Sims I, Cripps C (2006) Clay materials used in construction. Geological Society, London, Engineering Geology Special Publication 21: 513

\section{Your next submission with Juniper Publishers will reach you the below assets}

- Quality Editorial service

- Swift Peer Review

- Reprints availability

- E-prints Service

- Manuscript Podcast for convenient understanding

- Global attainment for your research

- Manuscript accessibility in different formats

( Pdf, E-pub, Full Text, Audio)

- Unceasing customer service

Track the below URL for one-step submission

https://juniperpublishers.com/online-submission.php 